\title{
Seeking Theoretical Common Ground: An Integrative Framework of Understanding Accountability for Service Delivery in the Community School in Nepal
}

\author{
Name: Kul Prasad Khanal \\ Email: ku1016@kusoed.edu.np \\ Accepted: 20 March 2019
}

\begin{abstract}
Existing literature provides ample evidence on how people understand accountability in different contexts. However, little attention has been paid on the integration of various theoretical perspectives about understanding accountability for education service delivery. Discussing theoretical premises against the empirical evidence from the community schools of Nepal, this article explores common ground of various theoretical perspectives about understanding school actors' accountability. It provides a framework for understanding accountability by integrating the ancient principle of 'karmayoga' and modern theoretical ingredients of structure-agency and knowledge-power. The article argues that both ancient and modern streams of theoretical perspectives are not mutually exclusive rather they share a common ground of process-based accountability which is embedded in broader concept of responsibility. Finally, the paper contributes to existing literature of accountability in education arguing that the school head's agency rather than working structure of the school played a significant role in creating an accountable space between the school head and other actors in the community school.
\end{abstract}

Keywords: accountability, neoliberalism, agency-structure, knowledge-power, karma-yoga.

\section{Introduction}

Accountability in education is a process of helping the school actors meets their responsibilities for effective delivery of services from the schools (United Nations Educational, Scientific and Cultural Organization [UNESCO], 2017). Responsibilities are the tasks assigned to the school actors either formally by education policy, laws and official directives or informally imposed by cultural norms, values and traditions of the school. Responsibility is also understood as "a willingness to act in a transparent, fair, compliant and equitable way." (Bovens, Schillemans, \& Goodin, 2014, p. 8). In meeting responsibilities, the school actors are obliged to account for their work to the beneficiaries of their services. Likewise, service delivery implies meeting expectations of the parents in terms of quality instruction in the school. To meet these expectations, the school actors: head teacher, teachers, School Management Committee (SMC) members, students and parents; perform their actions through the exploitation of resources at their disposal. In this reference, who is responsible for making decisions about acquisition, allocation and utilization of resources for better delivery of services has been a focus of accountability research in public education.

According to education act and regulations, the head teacher is the member secretary of the SMC as well as the executive head of the school (Government of Nepal [GoN], 2014). In this way his role is central for service delivery in the school. Being the executive head, the head teacher, basically, seems to be the provider of services and other actors of school such as teachers, students and parents are the seeker of services rendered by him. However, in their two-way interaction of delivering services, these actors intermittently swap their roles as service provider and service seeker. In this respect, accountability becomes a process of 
interactive social relationship (Bovens, 2010) between the service provider and the service seeker. This relationship works in a principal-agent model wherein principal works as a service seeker and agent as a service provider (Bruns, Filmer, \& Patrinos, 2011). This model is a simple way of understanding accountability relations between various actors of school. However, Yang (2012) finds many limitations of market-based principal-agent model of accountability in education.

There are significant concerns about accountability in education in global and national level. For instance, The Global Education Monitoring Report 2017 (UNESCO, 2017) highlighted the need for collaborative effort of school actors for sustainable service delivery in education. Suzuki (2002) identified four factors affecting accountability by the parents. The factors were: lack of transparency in school finance, power imbalance between the (head) teacher and parents, and distance between school leaders and other parents. He highlighted the need for installing accountability mechanism between the parents and the head teacher for head teacher's mismanagement. Sasoka and Nishimura (2010) with reference to Kenya, Uganda and Tanzania pointed out organizational culture of schools and the incentive mechanism of teachers and school administrators as barrier to unutilized power granted to the local level. The authors identified the need to establish accountability mechanism at central level in Kenya and at local level in other two countries. Likewise, Jaafar (2011) described professional accountability of the school actors using fivedimensional framework previously employed in Canada and the United Kingdom. The five dimensions were: testing structure, standard setting, consequential use of results, reporting, professional and involvement. Porter (2014) compared the client approach to accountability with citizenship approach in the educational context of Malawi and Kenya. The author explored whether education services were more responsive and accountable when young people accessed information and exercised their voice. They argued that a citizenship-led approach was likely to be more realistic and effective than a 'client power' approach. These works provided how accountability was realized in the context of local level. However, there was little discussion about how stakeholders' understanding was shaped by different theoretical beliefs.

Scholars also highlighted that market-based governance practices directed the public resources or service towards more affluent people making the public governance accountable to those who can pay the money for the services (Haque, 2000; Bhattacharya, 2003; Ambrosio, 2013; UNESCO, 2017). Harvey's (2006) observed that the neo-liberalism as restoration of class power and creative destruction implied that services were delivered inequitably making the service provider accountable to a comparatively well-off group of people. Ranson (2010) argued that "the dominant mode of answerability could not deliver achievement because it defined mistaken criteria of evaluating performance, emphasizing the external imposition of targets and quantifiable outcomes as the means of improvement" ( $p$. 470). In a similar fashion, Ambrosio (2013) found resistance to neo-liberal forms of accountability on the ground that "it fails to engender cultural ideals and values" (p. 316). Adding more, Bovens (2010) observed an "accountability trap" in which school actors were likely to meet accountability targets without any contribution to service delivery. Likewise, the Global Education Monitoring Report (2018) investigated that the high-stake testing was geared to the well-off students causing the poor students marginalized (UNESCO, 2017).

In the Nepali context, scholars have also raised two-fold issues of accountability in education. First, an inadequate resource resulted in the weak delivery of education services; 
second, school actors lacked accountability in managing the resources available (GoN, 2016; Poyck, Koirala, Aryal \& Sharma, 2016). Correspondingly, the author's professional experience and other research studies evidenced that school head's proactive initiatives in some schools found ways to fill the resource gap thereby demonstrating improved performance of the school (Department of Education, 2015). At the same time, some other schools were found entrenched in malpractices, informal governance and irregularities (Pherali, Smith \& Vaux, 2011; The Asia Foundation, 2012; Commission for Investigation of Abuse and Authority, 2015; Office of the Auditor General, 2015). Such situation raised a question of 'who is accountable for what, to whom and how' in utilization of scarce resources for delivering services in schools.

What theoretical and conceptual perspectives are used to interpret the understanding of accountability? Do various theoretical perspectives share a common ground of perceiving the notion of accountability? These questions are still unanswered. Apart from this, current decentralized governance in the federal structure of Nepal calls for local school actors to be accountable for the citizens they are serving. The new constitutional provision reverts accountability relationship from upward hierarchy to downward or horizontal accountability to the community where they are working. In this context, developing accountability mechanism (Bovens, 2010) requires an analysis of how people's understanding of being accountable is shaped and developed. Toward that end, this article contributes to seeking a common ground of various theoretical perspectives in relation to understanding school actors' accountability for service delivery in community schools of Nepal.

Methodologically, the article is based on a work 2016-2018 using a constructivist grounded theory approach (Charmaz, 2014) in two community schools of western Nepal. One was an urban school having abundant local resources and other a suburban school managed with limited resources. These schools were selected so as to explore the dynamics of accountability for service delivery in differently resourced contexts. The author spent most of the time in the field observing the school events, interviewing the school actors and studying the documents published by the schools. As findings of the study, the author developed six grounded theoretical categories of understanding school actors' accountability in community schools of Nepal. The categories were: accountability as managing resources, exercising autonomy, empowering actors, seeking integrity and building a two-way proactive relationship and accountability practice in paradox. Following the canon of grounded theory approach, the author followed theoretical sampling and constant comparative inquiry. That is to say, the provisional assumptions, categories, or issue led to further generation of data text or the research participant(s) (Charmaz, 2006; Charmaz, 2014). At the same time, the preliminary assumptions or categories were refined by comparing data to data, code and category constantly moving along bottom up and top down iterative process. In this way, the categories were developed independently of a theoretical lens. However, at the level of meaning-making, they were discussed in light of several data-indicated theoretical perspectives. This article presents how grounded theoretical categories of understanding accountability are viewed from the vantage point of related extant theoretical perspectives.

Likewise, the five categories of school actors such as school head teacher or principal, school management committee members, teachers, parents, and students were used as research participants. The focus was on accountability of head teacher who was the key actor (agent) for service delivery in the school. Other actors were the user (principal) (Bruns, Filmer \& Patrinos 2011; Bertelli, 2012) of services in the school. It was done so because the 
head teacher was the critical actor (Department for International Development [DFID] 2009; Acosta \& Pettit 2013) to make the change happen in the school. In pursuit of constructionist ontological ground (Bryman, 2016), the author used open-ended interview using triggers or probing questions relating to the theme of research questions. The preliminary categories were created using the inductive method. Such categories were reasoned through abductive inquiry by way of finding the best possible solution to the issues and assumptions emerged. Those assumptions were further verified deductively using further data. As such, the theory building process was an integrated use of inductive, abductive and deductive reasoning (Walton, 2004; Charmaz, 2014). The emerging theoretical assumptions or the issues provided a basis for the theoretical sampling of the research participants. Eventually, the meaningmaking process was accomplished locating the core category within an analytical framework of condition or context, strategies, and consequences (Strauss \& Corbin 1998; Creswell 2014; Charmaz, 2014). Such context and the strategies used by the research participants provided necessary ground for the author to discuss the findings in light of extant theoretical perspectives in question.

The remainder of the paper has been structured in terms of the theoretical perspectives that were used to discuss the grounded theoretical categories of understanding accountability. To this end, the article first deals with neo-liberal issues in accountability. Then, it talks about accountability in terms of agency and structure. Next, it discusses accountability with Foucauldian knowledge-power perspective. After that, the notion of accountability is viewed from the vantage point of 'karma-yoga' of ancient theoretical perspective. Finally, the paper winds up seeking a common ground of theoretical convergence in understanding accountability in education service delivery.

\section{Neoliberal issues in accountability}

Like many other developing countries, the political authority in power has influenced the education system in Nepal (Ministry of Education [MoE], 2009). The political change of 1990 facilitated the proliferation of private schools in the country. Since then, the education policy documents set their educational strategies in line with the neoliberal ideological ground. The seventh amendment of the Education Act, 2028 B. S. (seventh amendment 2058 B. S.), for instance, put the schools in two categories: the community schools and the institutional school. Community schools were the publicly funded and publicly managed schools whereas institutional schools belonged to privately funded and managed schools. The rhetoric of quality education was centred on competition, standardization, choice, efficiency, cost-effectiveness, achievement, role model and the like. Most of the community schools faced resource constraints followed by weaker management whereas institutional schools attracted the attention of parents by providing market-based choices and facilities under the strict management. More so, despite the legal provision of providing free education by the community schools, the comparatively resourceful schools adopted private school-like strategies to compete with the private counterparts for their survival. It was partly an influence of neoliberal governance paradigm adopted by the state (National Planning Commission, 1992, 1996) after the introduction of open socio-political system in the country.

Turner (2008) argued that in neo-liberal context, public services are delivered through contracting out to individuals or organizations through market-oriented strategies and rules. The government's role is restricted to the regulation of market-based institutions (Peters, Koirala \& Sharma, 2012). It is assumed that people are supposed to get public services more efficiently through open exchange mechanism. Scholars such as Haque (2000), Walker 
(2002) and Bhattacharya (2003) observed that as a result of neoliberal influence in education, some groups were likely to be more powerful than others and grabbed public resource and services. In the market-based service delivery, school activities were influenced more by the market institutions than by the state. This caused the domination of one group over the other creating inequitable accountability relationships between the service providers and the service seekers (Bhattacharya, 2003).

Under the influence of neoliberal governance paradigm, the notion of accountability was understood differently in different school contexts. For example, the suburban school was accountable to the public by offering admission to all for free. The suburban school located in the marginalized Muslim ethnic community would prefer to send their children to the local religious school-the Madrasa. This created two-fold challenge for the school namely raise parents' awareness for their children's schooling and compete with the private schools to attract and retain the students. By providing the private-school-like environment, the school attracted children from the private schools. However, in case of the urban school, the school enrolled the students through entrance exams and charging fees and donations to the parents. Surprisingly, the number of newly enrolled students came from the local private schools and crowded in the upper grades only. It was because the parents wished to enrol their children in the community school for two specific reasons viz. securing special facilities in higher study or public service offered by the government to community school graduates, and enjoying private-like learning facilities at relatively cheaper cost.

The students' profile recorded in the urban school supported that majority of the newly enrolled students were from comparatively better-off families. Very few students were found belonging to the laboring class family. The situation showed that the group of parents who opted for costly private school previously, redirected their children to the community school. The parents involved in the interaction remarked that despite the high fee structure, they preferred to send their children to private school because the quality of community school was poor. Later they found some community schools doing better and they came back. The parents were not against the community school. The better-off parents had choices to make and those who could not pay the private school remained in the community school. Such students of low-income families were vulnerable to dropping out or shifting the original school on account of not being able to compete with their private school counterparts in the entrance exam.

In above scenario, the sub-urban school seemed to be accountable to the public in general whereas the urban school was accountable to an aware or well-off group of people who could otherwise afford the private schooling of their children. This move of urban school kept the marginalized or disadvantaged groups aside through competitive entrance exams and enforcement of school fees. In this connection, the assistant head teacher in urban school opined, that it is difficult to cover all the expenses by government grants. If we do not provide learning choices to the students, the parents are likely to send their children to local private schools. Taking fee and donation is our survival strategy.

Based on these observations, it can be argued that market-based competitive practices put the community school at the crossroads of struggling for survival or striving for service. Under the neo-liberal educational policy, there appeared a proliferation of private schools, and at the same time government allowed the community schools to collect local resources of their own (GoN, 2014; Regmi, 2016). Schools were compelled to survive competitively through negotiation for fundraising from various sources. In the name of survival strategy, 
community schools' service was questioned in that they redirected their improved services toward an affluent group of people who could afford for the private schooling (Haque, 2000; Bhattacharya, 2003). In this context, the school actors' accountability role was distributed in terms of the financial level of the parents in the community.

\section{Agency-structure and accountability}

Power relations between individual and society have often been explained from agency and structure perspectives (Dowding, 2008; Elliott, 2014). From agency perspective, power resides in the action of the school actors or the school. School actors hold, wield, lose and gain the power through various interactions and contestations in the everyday activities of the school (Elliott, 2014). In this interactive process, their motivation, incentives and interests determine the form and type of power exercise on others (Dowding, 2008; Yang, 2012: Acosta \& Pettit, 2013). A structure perspective, on the other hand, views power in terms of social or cultural norms. Such norms and traditions are unconsciously internalized in school actors' thoughts and actions and shape their behavior (Yang, 2012; Acosta \& Pettit, 2013). In this dialectical relationship between the agency and structure, agents continuously (re) create the structure by transforming the existing rule of society in a novel way (Elliott, 2014). This process has been called structuration by Anthony Giddens (Giddens, 1984; Ritzer, 2000; Velotti \& Justice, 2016).

This perspective drew author's attention to learn whether the school head or the school's rules, norms and values influence the accountability relations in delivering services. In his study, the school head's proactive initiatives played critical roles in (re)producing the structure of accountability in the school. In doing so, he used his discretionary power (Behn, 2001 cited in Yang, 2012) and prior experience of the work he did in the school (Doshi, 2003). The existing work structure he has created determined the choices for other school actors in many ways for carrying out their daily activities. However, he was free to make such choices to perform the activities in creative and novel way (Ritzer, 2000; Doshi, 2003; Elliott, 2014).

In the study, in both suburban and urban schools, the head teachers used their power for managing resources through their social relation and network. To quote a parent in suburban school, "He has good relationship with high officials and political leaders and he brings money and teachers for the school". In the same fashion, in response to whose role was significant in resource generation, one of the SMC members in the urban school replied that "our head teacher is a teacher leader. He has good connection with other government officials. He can easily convince the authorized persons and grabs the funds for school". Head teacher's social recognition and interpersonal skills formed his social capital (Field, 2012). He developed his social capital through professional network, relationship with local donors and political workers. School head's coordinating strategy worked as a rich source of school income in the school. "Even if you don't have enough property, you can generate funding if you have a good coordination and relationship with others. Our head teacher has used this capacity very well", a secondary teacher added in suburban school. In this instance, human relations and their capacities worked as effective resource of the school. The head teacher used his social capital in various ways such as generating school resources, availing competent teaching force through personal relations, and building parents' trust and re/gaining school's goodwill. School actors consented that the coordination and convincing skills of the school head worked more than the cash property of the school. They perceived 
head teacher's accountability as being able to generate resources for the school using the personal or social network and relations.

Head teacher's strict and task-oriented management style brought about changes in school actors' behavior. In the words of a female parent in urban school argues that "since the arrival of this head teacher in this school, school is making significant progress. He is strict himself and coordinates well with the students". However, a female teacher in suburban school presented differently. She said that "head teacher is too strict. He hardly listens to us. Whatever he says we must carry out without question. He displays a kind of dictatorship in the school. Anyway, we must work hard otherwise we are likely to lose our job". Teachers were working in a strict working structure in the school, but this normative structure was established by head teacher's initiatives. Had he not been so strict on teachers' behavior, they would not have been working in a so restricted environment.

The above evidence confirmed that school head's power could be used for positive results as well (Lee-Chai \& Bargh, 2009). Such benevolent use of head teacher's power was identified as accountability attribute by the actors. By way of maintaining order in the school and working in his network, the head teacher's agency produced the new working structure in the school. This structure was created through a dialectical interaction of head teacher's reform initiative and the school's working culture. It was the process what Dowding (2008, p. 23) called "structurally suggested" interaction between agency and structure. Therefore, the exercise of social capital through agency became the head teacher's accountability feature in the school.

Pierre Bourdieu also explains the agency-structure relationship through his concepts of habitus, capital and field (Bourdieu, 1984 cited in Ritzer, 2000; Goddard, 2005). According to Bourdieu, habitus is a kind of mental disposition or cognitive structure (Jenkin, 1992; Ritzer, 2000; Best, 2003) through which school actors perceive, understand, appreciate and evaluate the social world of the school. It is reflected in the daily lifestyle choices of school actors such as playing, eating, teaching, evaluating and other leisure time activities of the school (Bourdieu, 1977; Harrington, 2005). The field is a network of relations among the objective positions school actors hold in the school (Wancquant, 1992 cited in Ritzer 2000). Bourdieu sees the field as an arena of struggle (Jenkin 1992; Goddard, 2005). He conceptualizes the field as a type of competitive marketplace in which various kinds of capitals (economic, cultural, social and symbolic) are employed and deployed continuously.

School, for example, is an example of the field. School actors carried their own mental dispositions, cultural values and legacies; they owned their social and cultural knowledge. Using this habitus and capital, they compete for their identity and goal achievement in the field of school organization. In the field of school, teachers, parents and SMC members had their own cognitive disposition based on the capital they possessed. Their association with different political organizations and ethnic or cultural values enabled them to place themselves in relation to others in the arena of struggle in school. In this situation, the head teacher created an accountability mechanism through the top-down command and the bottom-up reporting system. He imposed a kind of symbolic force (Dowding, 2008) on teachers as some teachers were at variance with him. An SMC member of the suburban school argued that "we are here just to put our signature on the minute of the meeting. Whatever the head teacher says and does is ok for us." They trusted the head teacher and depended on him for all they needed to do in the school. This showed that the accountability relationship between the head teacher and SMC looked like a patron-client relationship 
(Lindberg, 2013) where former worked as a master or patron and latter sought necessary services like a client from him.

In similar fashion, a female teacher in the urban school during a group interaction reported that they had no interest in debating with the head teacher. They feared of undervaluation of their performance. Viewed metaphorically, just like in a football match, all school actors had their own values and belief to win the game and compete accordingly. They wished to hold control over the resources in favour of their own interests. This habitus determined the degree to which an actor demonstrated their accountability roles both reactively and proactively (Desai, 2013). Viewing the situation from Bourdieu's perspective, the head teacher and other school actors would act in school with a varying combination of habitus, field and capital. He used his power to build hierarchical or managerial (Bovens, Schillemans \& Goodin, 2014) accountability relationships with the teachers and other actors. He was not doing this out of the existing structure only. An underlying structure (Dowding, 2008) worked behind his behavior. Using his habitus and the capital, he was continuously creating and recreating the existing working structure of the school. The top-down command and control and the bottom-up reporting mechanism along with delegation of tasks in teams were structural values created by the head teacher in the school. Such continuous modification in the structure took place through a dialectical interaction between the school actors' subjective agency and school's existing culture (Dowding, 2008; Ritzer, 2000). The head teacher's role of using social capital for resource generation, maintaining law and order, and creating a synergy of diverse ideas were his perceived accountability features. The head teacher through exercise of his power accomplished all this. In this way, in building accountable space between the school actors, he was continuously (re)creating the structure using his agency power in the school.

\section{Knowledge-power approach and accountability}

The previous section discussed the role of power resided in the school head's agency. Viewing the situation from other way around, the author also found that power was not always residing in the head teacher. It circulated among the school actors. The head teacher of urban school said that "I always wanted to maintain law and order in the workplace. In the past when I was a teacher, I proposed a reform plan in response to students' disruptive behavior. The head teacher's active agency grabbed the power and exercised it for creating the structure. To explain this situation, I took refuse in Foucault's theory of knowledge, power and truth. Foucault considers the interconnectedness of power, knowledge and truth through the discourse (as cited in Ritzer, 2000; Doshi, 2003). Accountability is also a kind of discourse. The discursive practices of accountability made powerful actors (the head teacher and his team) express control and authority over the powerless ones (other actors) (Focault, 1972; Kendall \& Wickham, 1999). Power is diffused and dispersed across the school actors and their behaviors (Ritzer, 2000).

Furthermore, the Foucauldian epistemology of discursive practice, epistemic layers of knowledge, gaze and panoptical surveillance have methodological bearings on exploring accountability relations between the school actors. Using Foucault's technique of 'gaze' school head teachers found areas to impose his sense of domination on parents and teachers. In urban schools, parents were diverting their choice from community schools to private schools. The head teacher and the SMC gazed on parents' sentiments and devised practical strategies to attract their attention. In this context, SMC chair claimed that "we knew parents 
have a deep passion for English medium instruction and other boarding school-like facilities. We grabbed this sentiment of the parents".

With the same token, the author found how the head teacher worked within his network and negotiated for fundraising through his network. It was an autopsy of rentseeking behavior. What was legally called corruption meant a simple gift exchange activity among the locals. The network of head teacher created a discourse of corruption in this way. SMC senior parent in the suburban school mentioned that "head teacher has to work for school. If he brings a big amount of money by losing a small chunk of it, it does no harm to the school. You know, something is better than nothing." Collusive behaviors were masked by the discourse created by the school actors. Being accountable was to show integrity and fairness in the daily performance. However, in some cases, school actors' subjective agency was reproducing the structural value of accepting small bribes and rents as normal for the sake of bigger amounts or benefits.

According to Foucault, change in the discourse could change the whole social structure (as cited in Ritzer, 2000; Doshi, 2003). In course of history, there had been changes in the discourse of accountability in the school. Discussing the shift in priority in the past, the Ex-SMC chair recalled that "previously the focus was on maintaining discipline in the school. Later, when I got appointed as SMC chair, we changed our emphasis to quality education delivery through better utilization of teacher and land resources." A different discourse of accountability was created by school actors' agencies that were in power at different times. In similar fashion, head teacher in the urban school added, "when I was a student, I revolted against the head teacher's malpractices in the misuse of resources. I became a teacher and went against the tyranny of the local administrator. Later, I supported the head teacher in maintaining the discipline in this school". Layers of episteme revealed that the head teacher was morally responsible for his actions at different times of his career history. This historically built disposition resulted in being accountable for what, to whom and how (Bhattacharya, 2003; Haque, 2000) of the school actors.

McHoul and Grace (1993) and Doshi (2003) acknowledged that in his work 'The History of Sexuality' Foucault turned upside down the traditional notion of sex. Metaphorically, just as prostitution was potentially a rebellion against women's economic, social and sexual roles, petty corruption could be understood as a compulsion of the school actors in school (Doshi, 2003). It was so because head teacher did not get incentives for the additional stuff he had to carry out in the school. To meet the additional expenses, he happened to seek sources of income by malfeasant means. This became the enticer of corruption in the school. Adding to this, the assistant head teacher in the suburban school remarked that the school should cover many unannounced costs in school. There is no separate cost category to manage such unannounced miscellaneous expenses. The school has to satisfy the officials or experts with the cash gift when we invite them in the school for teacher recruitment and the release of grants for the construction work. Further, the overhead cost like local transportation and other logistic facilities are to be covered in this way as well.

Ex-SMC chair and parents also consented to it. Just as prostitution was interpreted as a truth of life and a kind of compulsion for survival in Foucault's study, attitude towards corruption for some people seemed to be a kind of truth of public life in the community school. In this fashion, the meaning of accountability was interpreted through negotiation and sharing of power. The discourse of being accountable or exercising anti/corruption was created by these agents. People would accept the petty corruption as a normal practice 
according to the discourse established by the head teacher and his network. So, the head teacher's accountability to other actors was shaped by the discourse he established in the community. Knowledge-power perspective claims that in the post-modern world, only those with a large store of knowledge are powerful (Focault, 1972). It coincides with Francis Bacon's popular quote, "knowledge and power are like cause and effect" (as cited in Doshi, 2003). The experts who had knowledge of the subject constructed the discourse of accountability. The head teacher built the discourse of accountability and controlled the whole situation. All other actors followed him. Whatever he thought of the school became the accepted discourse for building accountability relations with parents and other actors.

All these theoretical ingredients discussed so far have their origin in the western world. We could see some clear ways that the different theories were coming together to build an understanding of accountability. However, none of these was contextually grounded in Nepalese socio-cultural context. This took the author to considering the principle of karmayoga which is going to be discussed in the following section.

\section{The principle of karma-yoga and accountability}

The term karma-yoga consists of two components viz. karma and yoga. Good action approved by the scriptures and accepted by the society denotes the term 'karma'. The evenness of mind is known as 'yoga' (Gita II, 48). Philosophically, the 'karma-yoga' means unionization of personal soul with that of the greater soul or the universal soul (the Paramatma or Brahma, the ultimate objective of being or reality) through the path of right or desireless actions. Symbolically, from my engagement with the research field, I realized that school as institution has its own soul-the mission of quality education. Despite changes in the school actors, this institutional soul never changes. In comparison, the society where the school resides has its own soul in the form of social development which is the ultimate objective of the school. The soul in the form of quality education transcends across school actors, school and the society.

In case of service delivery, the individual soul of the school actors needs to be unionized with that of the greater soul of the society to which they are accountable to. Ultimately, society is the user of services rendered by the school actors. So, it could be symbolized as the greater soul of the service delivery. When individual actions (or karma) are unionized with the greater societal expectations, the action of the actor is said to be based on the karma-yoga. The karma-yoga is the way of liberating the individual soul through the actions or good karma. Karma has to be performed with enthusiasm, with equanimity of mind, with no expectation of immediate desires and selfishness (Ramsukhadas, 2012). In this way, the essence of karma-yoga is in congruence with the nature of accountability relationship using action of the individual and the expectation of the forum (the society) (Bovens, Schillemans \& Goodin, 2014).

In whatever way people do actions, they have some value of doing it (Vaswani, 2011). The school head's life story in the community school showed that they struggled for achieving excellence and maintaining order in the school. They believed in working hard. When an urban school head teacher was just a teacher, he took initiatives to improve the school situation. In response to what motivated him to work for school, he remarked that "I wanted to work for my social recognition. The responsibility of head teacher given to me is an opportunity to make my social career which, I will enjoy even after my retirement." Similarly, the suburban school head teacher talked about his Muslim tradition of individual 
and social duty as enunciated in the Holy Scripture Hadith (Hallaq, 2009; Al-Ahadal, n.d.). Both head teachers respected doing karma or action under their own traditional value system. Commenting on the head teacher's performance, a critical teacher in suburban school added that "though head teacher is clever at persuading people for his agenda. He always remains active in school activities. So, by working as a head teacher he wants to earn social prestige and honor". In these instances, intrinsic value was working as a powerful drive for the action of the head teachers. They wished to utilize the present situation for the future and even lifelong gain as well.

Head teacher's commitment to work for the social recognition reflected the notion of 'karma' enunciated in the ancient perspective of the Bhagavad-Gita (Vaswani, 2011). It says, "कर्मणयेवाधिकारस्ते मा फलेषु कदाचनः। मा कर्मफलहेतुर्भुर्मा ते सड्गोऽत्वकर्मणि ॥२:४७॥ ."Krmanye wadhikaraste ma phaleshu kadachana. Ma karmaphalheturbhurma te sangoastakarmani. (Gita Press, 2011, $2: 47)$. [Human beings have the right to do their duty but not to be indulged in the fruits of it. Doing action is your duty. The fruits are naturally inherent in the action done. So, be worried about the action but not about its fruit]. This great verse says, unlike animals, only human beings have the right to do the good action to get liberated from the bondage of the karmic world. They believed that if they did good karma in their position of a head teacher, they could get its fruit of social recognition in the future. It implies that current professional life of school actors is the unique opportunity to do the right action. This will bring about the fruit of action in the form of flourishing professional life in the future. It suggests that when the actors are accountable for their action, their performance becomes result oriented leading to a better professional and social life in the future. It is kind of 'process-based' accountability (Cornelissen \& Walle, 2014).

As per 'karma yoga, the present state of human life depends on the results of past actions. It is the present action that decides the state of the life even after death (Ramsuskhdas, 2012). These different phases of life could be realized as 'pre-life, existing life and post-life or rebirth' signifying the concept of time as 'past, present and future' respectively. Linking the concept with accountability of school actors, the entire three-phase concept of time can also be translated and realized in the existing life itself - the life of individuals (the actors) and the life of the organization (the school). If we put an imaginary timeline on past, present and future, we can find that the current state of school actors depends on the previous action, and future actions have bearings on the present action. This linkage of past, present and future implies that one should be accountable for the performance of his or her works in the present. The present is essential as it provides foundation for the past and the future.

To illustrate, in karma-yoga philosophy, the 'atman' or the soul is immortal and transcendental and the physical body it resides is perishable. To quote the Gita, वासांसी जीर्णानी यथा विहाय नवानि गृह्लाति नरोपराणि। तथा शरीराणी विहाय जीर्णान्यन्यानि संयाति नवानि देही ॥२:२२॥ (Bhagavad-Gita, 2:22). It says that "wasansi jurnani yatha vihaya navani grihanti naroparani. Tatha sharirani vihaya jirnanyanyani sanyati nawani dehi". [Just like a man throws worn-out clothes and takes new ones, the embodied soul casts off worn-out bodies and enters into the new one]. As much as for the life of humans is transient but the soul is transcendental, the actors are in the temporary role of fixed duration in an organization. They work for a short time at different capacity, but the organizational values and principles are never-ending. The Gita says that the soul never dies; it just gets transformed into different shapes as per the body it occupies. 
As the above verse states, the life of an individual is transient but the soul which resides in it is permanent and transcendental. Analogically, being a part of an organization, the head teacher or school actors are the actors whose professional life in the school is temporary but the school's values and principles form the organizational soul, which is permanent and immortal. School actors get changed like the physical body, but organization value of providing quality education never ends, it only gets transformed as per the school head or actors who work for it. School actors' current actions determine the future state of school affecting the organizational soul. After a passage of time, the present turns into the past, and the future becomes the present. It continues endlessly. The transient school head or actors pass on the organizational soul from one body to other (the school head or actors). A significant portrayal of this concept is presented in the Figure 1.

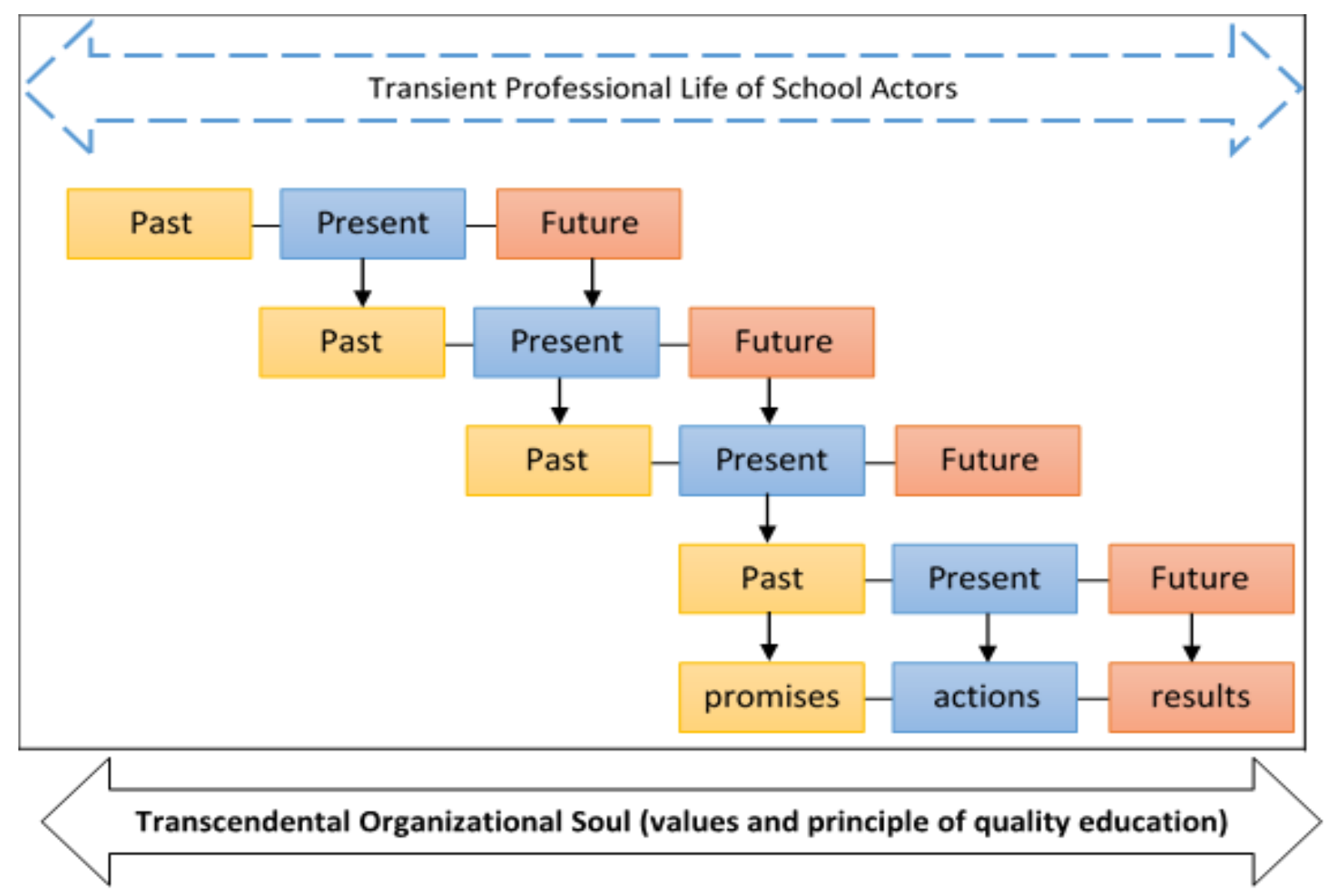

Adapted from the Bhagavad-Gita 2:22 and 2:47 (Gita Press, 2011).

Figure 1. Conceptualization of time segment in realizing accountability along karma-yoga.

The Figure 1 shows the concept of moral accountability on a temporal dimension. It implies that whatever a school actor does at the present time affects the future state. Past activities have present consequences, and present actions, in turn, have future consequences. The present is more powerful as it is all about past and present. It is related to historically developed habitus and the historical base of structure and agency (Bourdieu, 1977; Ritzer, 2000). This concept also coincides with the historical or temporal development of discourse in knowledge-power perspective and historical legacy of actors. The knowledgeable actors creates the discourse of accountability and wields power. The transient professional life of the head teacher carries the transcendental soul of the organizational soul of the school. Historically, the head teachers are changed but the organizational soul remains unchanged. This greater soul gets its shape depending upon the head teacher it embodies in a particular 
segment of time. For the professional life of the head teacher, the time is segmented into past, present and future. In other words, when he is unionized with the organizational soul, his actions are great and he is liberated; and he reaps the fruits of his present action in the form of good results or recognition after the retirement or rebirth after the professional life in future.

The actions of the school actors account for their responsibility that is the foundation of accountability relations. As per the law of karma, the present responsibility of karma decides the future destiny of the actors. They become responsible when their speech is in congruence with their action. The author found contradictory behaviors of his research participants. In some occasions, the head teachers put emphasis on the present action to build their future destiny. In some other occasions, they exercised their agency power over other actors which did not seem to go with their words. In this context, the sub-urban head teacher, opined that "I have made everything transparent. I have developed the morale of my teachers and so on". Other actors reported that behind the mask of public consent on some development activities, he was engaged in some collusive and rent-seeking behaviors in his network with other personnel. A formal accountability mechanism of social audit, as for example, ended up with just ritual practice. Likewise, in the urban school, the head teacher and SMC members felt pride in providing better facilities as demanded by the parents. The government also nationally awarded the school for improved performance (MoE, 2015). However, as discussed in the previous section, by providing instructional choices for fee and donation, they were accountable to the well-off group of people. This paradoxical accountability situation could be explained using the moral principal of the Rig Veda which has been illustrated as peace message (shanti patha) in the Upanishads ॐ वाङ् मे मनसि प्रतिष्ठता मनो मे वाचि प्रतिष्ठितमाविराविर्य एधि। वेदस्य म आणीस्थ श्रुतं मे मा प्रहासी: ॥ अनेनाधीतेनाहोरात्रान् संदधाम्यदतं वदिष्यामि। सत्यं वदिष्यामि। तन्मामवतु। तद्वक्तारमवतु। अवतु मामवतु वक्तारमवतु वक्तारम् ॥ ॐ शान्तिः। ॐ शान्तिः॥ ॐ शान्तिः॥". It says, "Om vangme manasi pratisthita mano me wachi pratisthitamawirawirya edhi. Vedasya ma aanistha shrutam me ma prahasi. Anenashitenahoratran samdadhyamreitam vadisyami. Satyam vadisyami. Tanmawawatu. Tadwaktarmavatu. Awatu mamawatu vaktaram. Om Shanti. Om Shanti. Om shanti." [It means let my speech be established in my mind. Let my mind be established in my speech. Let me continuously live my days and nights in my studies. Let me speak the truth (Gita Press, 2011.)]. This Vedic hymn is the symbol of moral accountability. When actors flow this principle, they become morally responsible. When they are responsible, everything is in order that is the ultimate peace everywhere.

From the karma yoga perspective being accountable meant being morally responsible to one's duty and being in congruent with one's speech and actions. Being morally responsible made agency of the actor (i.e. the head teacher) important. In view of prominent role of the head teacher's agency in building accountability relationships, a point of common ground is sought in terms of different theoretical premises given below.

\section{Finding the theoretical common ground}

For conceptualization, the theoretical premises discussed have been placed in two different camps-the modern and ancient perspective. The West-originated theoretical premises are treated as modern theories whereas an eastern theoretical ingredient (i.e. the karma-yoga) is known as ancient or traditional. Modern theoretical perspectives like neoliberal ideology, knowledge-power relationship and agency-structure discussed in this article seemed to have been manipulated under the influence of market-based governance practices. This viewed the situation of accountability in a discrete form based on work-based conditions, standards and 
indicators whereas from ancient perspectives accountability is understood more holistically (Puligandla, 2008). Such holistic nature of accountability gives a perfect or comprehensive meaning of being accountable for service delivery. The popular peace verse of the Upanishad (Shanti Patha) below conveys this concept of perfectness. "ॐ पूर्णमदः पूर्णमिदं पूर्णात् पूर्णमुदच्यते । पूर्णस्य पूर्णमादाय पूर्णमेवावशिष्यते ॥ ॐ शान्तिः ॐ शान्तिः ॐ शान्तिः" This invocatory verse says that "Om poornamadah poornamidam poornaat poornamudachyate. Poornasya poornamaadaaya poornamevaavashishsyate. Om peace, Om peace, Om peace." (Ishavasya Upanishad). [This is perfect. That is perfect. This universal form of Brahma is the complete whole. The part of this complete whole is also complete]. Analogically, the role of school as an organization of service provider seems perfect in its mission of providing quality education; and the community or society as service seeker expects a perfect form of service from the school. Even if a part of larger society is taken out, both the segmented part and the original society carry all the features of society which is perfect in itself. The school head teacher representing the organization is perfect when he performs his or her duties for society aligning his service objective with that of the organization. This implies that the perfectness in accountability is exercised when both the actors (i.e. the service provider and the service seeker) feel a sense of perfectness based on their moral obligations. When the head teacher is morally responsible for his action, he performs the desire less action in which all ingredients of accountability like giving accounts and justification, standards, sanctioning incentive become a perfectly inbuilt part of the action performed.

In addition, the modern perspective of knowledge building seems more inductive, starts from the process or evidence, and makes a conclusion at the end. The ancient tradition, on the other hand, appears more deductive in nature, starts from the conclusion, and goes onto testing it in the process. The notion of accountability from this vantage point is conceived from two different perspectives. The ancient perspective is related to intrinsically originate moral value (Chatterji, 2013). The modern perspective views accountability by breaking down the working conditions like delegation of authority, resource, performance, information, enforcement and so on (Ackerman, 2004; World Bank, 2003). As for example, perspectives of neoliberalism, knowledge-power relations and structure-agency interpret the notion of accountability in terms of the actors' performance. The focus is on the output of the action performed. From ancient 'karma-yoga' perspective, when an actor is morally responsible, he or she is naturally accountable to oneself for his or her performance. The focus in this way is on the process rather than on the product or results of the action.

Nevertheless, both perspectives have a common ground that the process-based accountability rather than the output or the results-based accountability is more important for service delivery. Giving emphasis on the desire less action is concerned with being accountable for the process of the action whereas being accountable for the result is likely to pave the way for malfeasant behavior as discussed earlier. On this ground, two theoretical perspectives seemed to be complementary to each other (Radhakrishnan, Wadia, Datta, \& Kabir,1953; Das, 1952) making the notion of being accountable meaningful within the broader concept of responsibility. As such, the process of accountability integrated into responsibility provides a ground for both theoretical streams of perspectives. This concept is visualized in the following figure. 


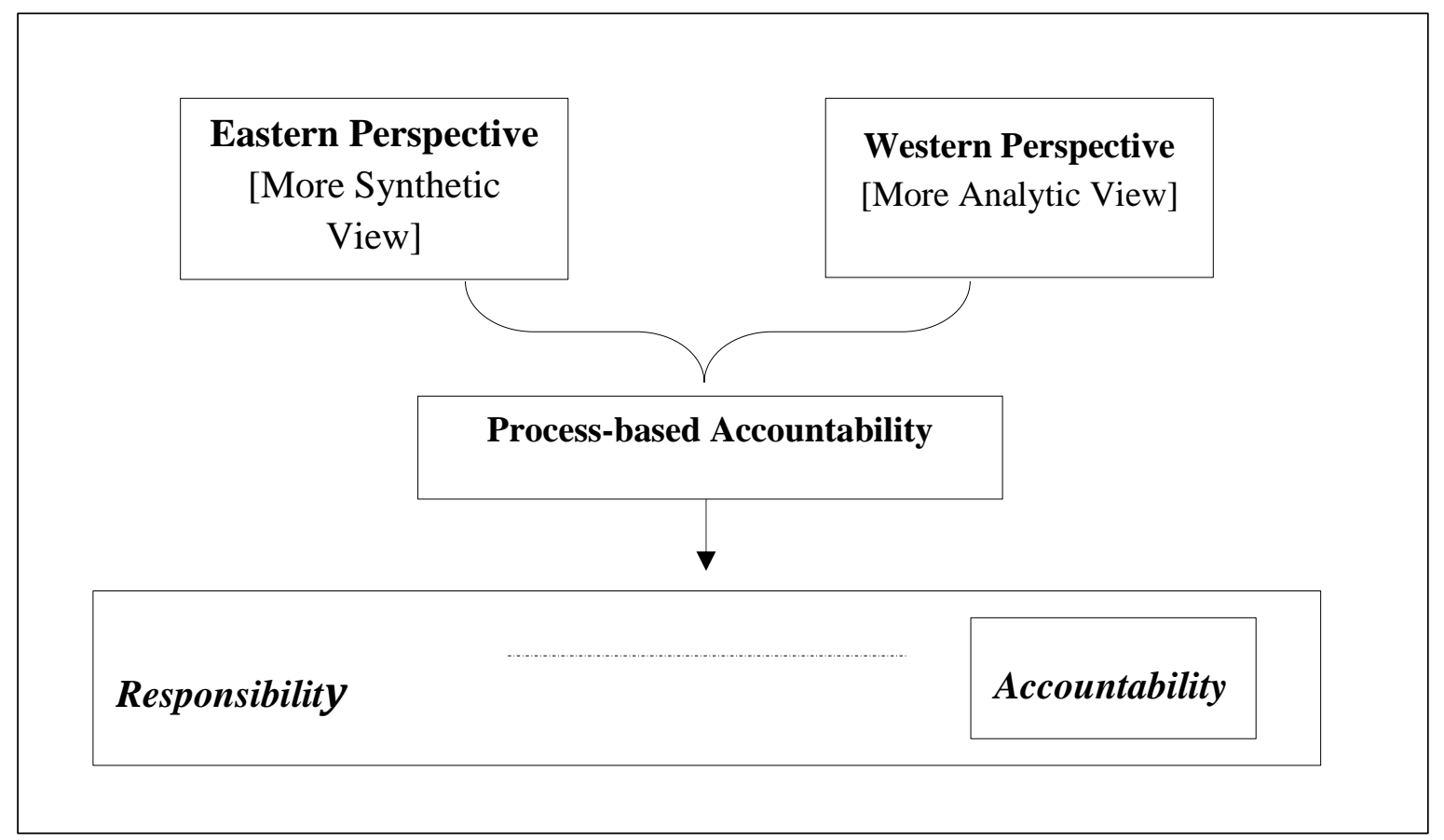

Adapted from Radhakrishnan, Wadia, Datta, \& Kabir (1957) and Das (1952).

Figure 2: Common theoretical ground on accountability.

The figure 2 shows that a process-based accountability provides a common ground for both theoretical streams. The notion of accountability is embedded into overarching concept of responsibility. It implies that once school actors are responsible for intrinsically imposed moral obligation, they are accountable for their actions. When they are responsible, they give an account of their performance proactively irrespective of any mechanism in place. The morally built-in mechanism guides them. In other words, the more synthetic view of eastern perspective implies that school actors are accountable to one self. It is the moral obligation embedded into the notion of responsibility (Radhakrishnan, Wadia, Datta, \& Kabir,1953; Das, 1952). On the other hand, from the more analytic western perspective, the actors are likely to be accountable to others based on their manipulated results. At this point, it can be argued that when a person is morally responsible, he or she is accountable to oneself and to the others as well. This is the essence of Gita's perspective grounded in Nepalese tradition.

As mentioned earlier, in the eastern perspective of karma yoga, the individual is made up of two parts viz. the body and the soul. Body or senses perform the action and soul does nothing (Chatterji, 2013). The individual soul becomes the part of the broader organizational soul (the universe) which gives a perfect meaning of being accountable. The greater soul is only the seer of the actions of the actors. Even though an individual is independent to perform his or her action, he or she is morally guided by the independent soul resided in him or her. This is what responsibility does. Under this moral guidance, the actor's independent subjective agency creates organizational changes. This becomes an objective structure of the organization. In this way, the dialectical nature of agency and structure is also reflected in the 'karma-yoga' where actor's agency is seen prominent in building the structural changes in the work context. 


\section{Conclusion}

This article discusses the possibility of integrating various theoretical perspectives in understanding the notion of accountability for service delivery in education. The core grounded theoretical categories of understanding accountability have been viewed from the vantage point of key data-indicated extant theoretical premises of neoliberalism, agencystructure, knowledge-power, an ancient principle of karma-yoga. In the context of neoliberalism or market-based governance mechanism, accountability implies addressing the needs of better-off people. From the agency-structure perspective, being accountable means demonstrating head teacher's social capital in generating resources and maintaining order in the school by imposing his or her domination. From the knowledge-power perspective, accountability meant sharing of power among the school actors. It was predominantly affected by the discourse created by the head teacher and his or her network. Putting these theoretical premises in two camps of ancient and modern perspectives, the author attempted to view the notion of accountability in terms of being accountable to one-self and being accountable to other.

Finally, the article illustrates that the notion of accountability can be understood by bringing together various theoretical perspectives on a common ground of process-based accountability. In this process, the agency of the school actors remains prominent in building accountability relationships among the school actors. Besides, the integrative understanding of accountability calls for devising an accountability mechanism in which the school head becomes morally responsible at the same time being a beneficent administrator in the school. By drawing on this integrative model of understanding of accountability, it seems possible to develop the accountable leadership capacity development scheme of the school head to exert his or her proactive initiatives making him responsible through union of individual soul (i.e. individual objective) with the organizational soul (i.e. school's objective or mission). Last but not the least, the integrative theoretical framework of understanding accountability could become a starting point to conduct further case studies on school actors' accountability in different socio-political contexts, particularly the service delivery at the local level in newly introduced federal structure of education in Nepal.

\section{References}

Ackerman, J. (2004). State-society synergy for accountability: Lessons for the World Bank. Washington, D.C.: The World Bank.

Acosta, A. M., \& Pettit, J. (2013). Practice guide: A combined approach to political economy and power analysis. Discussion note prepared for the Swiss Development Cooperation. Aswan, Egypt: Institute of Development Studies.

Al-Ahadal, Pro. Hashim Ali (n.d.). व्यक्तिगत शिक्षा: किताब व सुन्नतको प्रकाशमा (Baktigat Shiksha: Kitab Wa Sunnatko Prakashma). Edited by Mohammad Harun Ansari. Bhairahawa: Aslaam Manav Seva Shangh.

Ambrosio, J. (2013). Changing the Subject: Neoliberalism and accountability in public education. Educational Studies, 49(4), 316-333. doi:10.1080/00131946.2013.783835

Bertelli, A. M. (2012). The political economy of public sector governance. Delhi: Cambridge University Press.

Best, S. (2003). A beginner's guide to social theory. New Delhi: Sage Publication.

Bhattacharya, M. (2003). Nexus between accountability and good governance: Conceptual 
and practical issues. In P. Sahni \& U. Medury (Eds.), Governance for Development (pp. 33-47). New Delhi: Prentice-Hall of India Private Limited.

Bourdieu, P. (1977). Outline of a theory of practice. Cambridge Studies in Social Anthropology 16 (16): 248. doi:10.1590/S0103-20702013000100001

Bourdieu, P. (1984). Homo academicus. California: Stanford University Press.

Bovens, M. (2010). Two concepts of accountability: Accountability as a virtue and as a Mechanism. West European Politics, 33(5), 946-967. doi:10.1080/01402382.2010.486119

Bovens, M., Schillemans, T., \& Goodin, R. E. (2014). Public accountability. In The oxford handbook of public accountability (pp. 1-20). Oxford: Oxford University Press.

Bruns, B., Filmer, D., \& Patrinos, H. A. (2011). Making school work: New evidence on accountability reform. Washington D.C.: The World Bank.

Bryman, A. (2016\}. Social research methods. New York: Oxford University Press.

Charmaz, C. (2014). Constructing grounded theory ( $2^{\text {nd }}$ Ed.). New Delhi: Sage Publication India Ltd.

Chatterji, B, K. (2013). Karmayoga in the Gita. Kalyana-kalpataru: Karmayoga number 59 (1): 161-70.

Commission for Investigation of Abuse and Authority. (2015). Twenty-fourth annual report (2013/14). Kathmandu: Commission for the Investigation of Abuse of Authority.

Cornelissen, F., \& Walle, S. V. D. (2014). Performance reporting. In The Oxford Handbook of Public Accountability, edited by Mark Bovens, Robert E. Goodin and Thomas Schillemans, 441-455. London: Oxford University Press.

Creswell (2014). Educational research: planning, conducting, and evaluating quantitative and qualitative research (5th ed.). Sydney: Pearson.

Das, A. C. (1952). Similarities in eastern and western philosophy. The Review of Metaphysics, 5(4), pp 631-638.

Department of Education (2015). Status report 2014/2015. Sanothimi: Department of Education.

Desai, J. P. (2013). Accountability: Angst, awareness, action. Delhi: Pearson.

DfID, D. for I. D. (2009). Political economy analysis: How to Note. A DFID Practice Paper, (July), 1-29. Retrieved from http://www.odi.org/sites/odi.org.uk/files/odiassets/events-documents/3797.

Doshi, S. L. (2003). Modernity, postmodernity and neo-sociological theories. Jaipur: Rawat Publications.

Dowding, K. (2008). Agency and structure: Interpreting power relationships. Journal of Power, 1(1), 21-36. https://doi.org/10.1080/17540290801943380

Elliott, A. (2014). Contemporary social theory: An Introduction. London: Routledge. doi:10.1016/j.aca.2011.08.052.

Field, J. (2012). Social capital (2nd ed.). London: Routledge.

Focault, M. (1972). The Archaeology of knowledge. London: Harper Torchbooks

Giddens, A. (1984). The constitution of society: Outline of the theory of structuration. Polity Press: Cambridge.

Gita Press. (2011). Srimad Bhagavad-Gita: Sanskrit text with Hindi and English translation (code1658). Gorakhpur: Gita Press.

Goddard, A. (2005). Accounting and NPM in UK local government: Contributions towards governance and accountability. Financial Accountability \& Management 21 (2): 191218. doi:10.1111/j.1468-0408.2005.00215 
Government of Nepal (2014.). Education act 2028 (with amendments) and education regulation (with amendments) 2059. Kathmandu: Government of Nepal.

Government of Nepal. (2016). School sector development plan (SSDP) 2016-2023. Ministry of Education. Retrieved from www.moe.gov.np

Hallaq, W. B. (2009). An introduction to Islamic law. Cambridge: Cambridge University Press.

Haque, M. S. (2000). Significance of accountability under the new approach to public governance. International Review of Administrative Sciences, 66(200012), 599-617.

Harrington, A. (2005). Modern social theory: an introduction. New York: Oxford University Press.

Harvey, D. (2006). Neo-liberalism as creative destruction. Geography and Power, the Power of Geography, 88(2), 145-158.

Jaafar S. B. (2011). Performance-based accountability in Qatar: A state in progress. Compare: A Journal of Comparative and International Education, 41:5, 597-614, doi: 10.1080/03057925.2011.555139

Jenkin, R. (1992). Pierre Bourdieu. New York: Routledge.

Kendall, G., \& Wickham, W. (1999). Using Foucault's methods. London: Sage Publications. doi: $10.4135 / 9780857020239$

Lee-Chai, A. Y., \& Bargh, J. A. (2001). The use and abuse of power. Philadelphia: Psychology Press.

Lindberg, S. I. (2013). Mapping accountability: Core concept and subtypes. International Review of Administrative Sciences, 79(2), 202-226. doi.10.1177/0020852313477761

McHoul, A., \& Grace, W. (1993). A Foucault primer: Discourse, power and the subject. New York: Melbourne University Press.

Ministry of Education (2015). $36^{\text {th }}$ National education day-2072 and international literacy day program booklet. Kathmandu: Ministry of Education.

Ministry of Education (2009). Compendium on education policy in Nepal. Kathmandu: Ministry of Education.

National Planning Commission (1992). The eighth five-year plan (1992-1997). Kathmandu: National Planning Commission.

National Planning Commission (1996). The ninth five-year plan (1996-2002). Kathmandu: National Planning Commission.

Office of the Auditor General. (2015). Annual report of the Auditor General 2015. Kathmandu: Office of the Auditor General.

Peters, M. A, and Peter, L. (2012). Neoliberalism and after? Education, social policy, and the crisis of western capitalism. International Review of Education. 58: 585-87. doi:10.1007/s11159-012-9300

Pherali, T. J., Smith, A., \& Vaux, T. (2011). A Political economy analysis of education in Nepal. Kathmandu. Retrieved from http://uir.ulster.ac.uk/30667/1/Pherali_Smith_Vaux

Porter, C. (2014). Turning old problems into new problems: The role of young citizens in improving accountability in education in Malawi and Kenya, Compare: A Journal of Comparative and International Education, 44:3, 356-378, doi: 10.1080/03057925.2013.778535

Poyck, M. C., Koirala, B. N., Aryal, P. N., \& Kishor, S. N. (2016). Joint evaluation of Nepal's school sector reform Pplan 2009-2016. Kathmandu: Ministry of Education.

Puligandla, R. (2008). Fundamentals of Indian philosophy. New Delhi: D. K. Printworld (P) 
Ltd.

Radhakrishnan, S., Wadia, A. R., Datta, D. M., \& Kabir, H. (1957). History of philosophy eastern and western (Vol. I). London: George Allen \& Unwin Ltd.

Ramsukhdas, S. (2012). Srîmad bhagavadgîtã (Sadhaka-Sañjîvanî [with appendix] Vol. I. Gorakhpur: Gita Press.

Ranson, S. (2010). Public accountability in the age of neoliberal governance. Journal of Education Policy, 37-41. doi.10.1080/0268093032000124848

Regmi, K. D. (2016). World Bank in Nepal's education: Three decades of neoliberal reform. Globalization, Societies and Education. doi.10.1080/14767724.2016.1169517

Ritzer, G. (2000). Sociological theory (5th ed.). New Delhi: McGraw-Hill Higher Education.

Sasaoka, Y. \& Nishimura, M. (2010). Does universal primary education policy weaken decentralization? Participation and accountability frameworks in East Africa. Compare: A Journal of Comparative and International Education, 40(1), 79-95. doi: 10.1080/03057920902913875

Strauss, A. \& Corbin, J. (1994). Grounded theory methodology: An overview. In N. Denzin \& Y. Lincoln (Ed.), Handbook of Qualitative Research (pp. 273-285). Thousand Oaks: SAGE Publications Ltd.

Suzuki, I. (2002). Parental participation and accountability in primary schools in Uganda. Compare: A Journal of Comparative and International Education, 32(2). doi: 10.1080/03057920220143200

The Asia Foundation (n.d.). Political economy analysis of local governance in Nepal with special reference to education and health sector. Kathmandu: The Asia Foundation.

Turner, R. S. (2008). Neo-liberal ideology: History, concepts and policies. Edinburgh: Edinburgh University Press Ltd.

United Nations Educational, Scientific and Cultural Organization (2017). Global education monitoring report 2017/18. Accountability in education: Meeting our commitments. Paris: United Nations Educational, Scientific and Cultural Organization.

Vaswani, J. P. 2011. The seven commandments of the Bhagavad-Gita. Edited and compiled by Prabha Sampath and Krishna Kumari. Delhi: Jaico Publications.

Velotti, L., \& Jonathan B. J. (2016). Operationalizing Giddens's recursive model of accountability." Public Performance and Management Review, 40 (2), 310-35. doi:10.1080/15309576.2016.1207549

Walker, P. (2002). Understanding Accountability: Theoretical models and their implications for social service organizations. Social Policy and Administration, 36(1), 62-75. doi:10.1111/1467-9515.00270

Walton, D. (2004). Abductive reasoning. Tuscaloosa: The University of Alabama Press.

World Bank (2003). The World Bank report 2004: Making services work for poor people. Washington, D.C.: The World Bank.

Yang, K. (2012). Further understanding accountability in public organizations. Administration \& Society, 44(3), 255-284. doi.10.1177/0095399711417699 